\title{
Lean Manufacturing Integration in Reducing the Number of Defects in the Finish Grinding Disk Brake with DMAIC and FMEA Methods in the Automotive Sub Industry Company
}

\author{
Atep Afia Hidayat ${ }^{1 *}$, Muhammad Kholil ${ }^{1}$, Jakfat Haekal ${ }^{1}$, \\ Nurul Aisah Ayuni ${ }^{1}$ and Tri Widodo ${ }^{2}$
}

${ }^{1}$ Department of Industrial Engineering, Universitas Mercu Buana, DKI Jakarta, Indonesia

2Universitas Islam Muhammadiyah Tanggerang, DKI Jakarta, Indonesia

*Corresponding author details: Atep Afia Hidayat; atepafia@mercubuana.ac.id

\begin{abstract}
This automotive company is a company engaged in the automotive components of motorcycles. Its main product is Disk Brake. Automotive companies produced an average defective product in Disk Brake production for the January 2019 - December 2019 period of $1.72 \%$, while the tolerance limit of the company was $1 \%$, where there was a difference of $0.72 \%$. This study aims to reduce the number of defects by providing recommendations for improvement proposals. The method used is DMAIC (Define, Measure, Analyze, Improve, Control) by calculating the company's sigma value and using FMEA (Failure Mode and Effect Analysis) tools to improve the problem. The Define stage creates SIPOC and CTQ (Critical to Quality) diagrams. At the Measure stage, the results of the calculation of the sigma value obtained a DPMO of 3446.41 with a sigma value of 4.20 . The most dominant type of defect in disk brakes is thin material based on the analysis results using the Pareto diagram at the Analyze stage. The causes of disk brake defects are obtained using a fishbone diagram. At the Improve stage, the FMEA calculation found the most potential problem-causing factors, namely the availability of components with an RPN (Risk Priority Number) value of 448 and $5 \mathrm{~W}+1 \mathrm{H}$ analysis, an improvement proposal was obtained to schedule maintenance and replacement of components regularly.
\end{abstract}

Keywords: disk brake; defect; DMAIC; FMEA

\section{INTRODUCTION}

Companies engaged in the automotive sector in Indonesia are currently growing quite rapidly. Companies must be able to withstand industrial competition. Companies also have to keep up with developments and know the tastes of consumers. To fulfill consumer desires for high-quality goods, companies are required to provide good quality products. To improve the excellent quality of the product, it is necessary to have quality control. Quality control can be done with various approaches and methods, one of which is using the Six Sigma (DMAIC) method. DMAIC is a methodology used in Six Sigma to solve problems that arise; this method is repeated to improve the improvement process continuously.

Automotive industry company which is engaged in the manufacture of automotive components. Its main products are Disk Brakes for various two-wheeled motor vehicles. Customers include large companies such as Honda and Yamaha. Based on this, the company always pays attention to all production activities starting from the production system, raw materials, labor, etc. In producing Disk Brake components, several process stages are carried out, such as Press, Heat Treatment, Cutting, Mounting Hole Drilling, Counter Bore, Painting, Grinding. Disk brakes have various parts, namely A38, A39, A40, A41, and A42. In the production process, the Disk Brake component experiences various problems, so that it has an impact on the resulting product, it can be seen from the high number of Disk Brake product defects. Based on the process in the production of Disk Brake, most product defects occur in the grinding process. So, we need quality control tools to find these solutions. The following is data on the number of production and the number of defects in Disk Brake products for the period January 2020- December 2-20:

TABLE 1: Total Production and Number of Disk Brake Defects Products in the Grinding Process from January 2020 to December 2020

\begin{tabular}{|c|c|c|c|c|}
\hline No & Month & Product & Defect & Percentage \\
\hline 1 & January & 17182 & 300 & $1.75 \%$ \\
\hline 2 & February & 18505 & 310 & $1.68 \%$ \\
\hline 3 & March & 20225 & 330 & $1.63 \%$ \\
\hline 4 & April & 17273 & 320 & $1.85 \%$ \\
\hline 5 & May & 20063 & 343 & $1.71 \%$ \\
\hline 6 & June & 13600 & 245 & $1.80 \%$ \\
\hline 7 & July & 19734 & 340 & $1.72 \%$ \\
\hline 8 & August & 17383 & 295 & $1.70 \%$ \\
\hline 9 & September & 13870 & 246 & $1.77 \%$ \\
\hline 10 & October & 19552 & 320 & $1.64 \%$ \\
\hline 11 & November & 20805 & 341 & $1.64 \%$ \\
\hline 12 & December & 14448 & 259 & $1.79 \%$ \\
\hline & Total & 212640 & 3649 & \\
\hline
\end{tabular}


Based on table 1, it is known that Disk Brake products have several defects exceeding $1 \%$ every month. This proportion exceeds the defect limit allowed by the company, which should only be $1 \%$ of the total production. Therefore, to reduce the level of product defect, a study was conducted to determine the types of defects that have a high effect on Disc Brake products and provide suggestions for improvements to the defects that occur using the DMAIC method (Define, Measure, Analyze, Improvement, Control). Based on the above, the researcher conducted a study with the title: "Lean Manufacturing Design to Reduce the Number of Defects in the Finish Grinding Disc Brake Process with the DMAIC and FMEA Method Approach in Automotive Companies."

\section{RESEARCH METHODOLOGY}

The research method is a stage that must be determined in advance before solving a problem that will be carried out in researching so that research can be carried out in a directed manner and makes it easier to analyze the problems that will be carried out in the research. The stages in this research include initial observation, literature study, introduction, theoretical basis, data collection, data processing, analysis, and conclusions and suggestions.

\section{Type of Research}

This study, using quantitative research methods because its implementation includes processing data in the form of numbers or numbers. By its form, quantitative data can be processed or analyzed using mathematical calculation techniques.

\section{Types of Data and Information}

The types of data and information used in this study are as follows:

Primary data: Primary data is data collected directly by the author; in this study, the primary data used is the author's interview data with supervisor quality control and production leaders to determine the CTQ (Critical to Quality) criteria and to find out the RPN value from FMEA (Failure Mode) And Effect Analysis). In addition, the authors conducted interviews with production operators to determine the causes of defects that occurred.

Secondary data: Data obtained indirectly from other parties. In this study, the secondary data used were production data and disc brake defect product data.

\section{Data Collection Methods}

Data collection is needed to obtain information related to the object to be studied. The method shows a way so that its use can be shown through questionnaires, interviews, observations, tests, documentation, etc.

The data collection used in this study are as follows:

\section{(1) Direct Research}

Field studies are conducting direct reviews to obtain the data needed in the preparation of the final project. This research was conducted on the activities of all objects which include:

a. Observation is a complex data collection method because it involves various factors in its implementation. Observational data collection methods not only measure the attitudes of respondents, but can also be used to record various phenomena that occur.

The interview is a data collection technique carried out through face-to-face and direct question and answers to the quality control supervisor and Production Leader to obtain the data needed in the study.

Distributing a questionnaire (questionnaire) is a set of questions that logically relate to a research problem. The researcher made a list of questions shown to the head of
Quality Control as part of the fishbone results to obtain the RPN value from FMEA (Failure Mode and Effect Analysis).

\section{(2) Literature study}

Namely, the technique of collecting data from various library materials (Reference) that is relevant and studies related to the issues to be discussed. Reference sources used come from various books that support the use of the six-sigma method (DMAIC), FMEA, international journals, PASTI journals and various other literature that support research so that the research used can be universal and with applicable rules.

\section{Data Processing and Analysis Methods}

The stages carried out in processing and analyzing data are as follows:

Identify the product manufacturing process. The first step in the research is to understand how the disc brake production process occurs from raw materials to finished products. Data collection the collection of data needed in conducting this research includes data on the number of production and data on defective products in the Disc Brake for the period January - December 2020, as well as observation and interview data to determine the causes of defects so that they can provide solutions to the company.

\section{DMAIC method (Define, Measure, Analyze, Improve, Control) \\ - Define}

At the define stage, problem identification is carried out, starting with defining each type of defect that occurs in Disc Brake products, then continuing with the determination of CTQ (Critical to Quality) to know what kind of product the customer wants.

\section{- Measure}

In this stage, the value of DPMO (Defect per Million Opportunities) and SQL (Sigma Quality Level) will be determined, and a Yield calculation will be made to determine the probability of a product that is not defective in the Disc Brake production process.

Furthermore, the DPMO value is converted to the Six Sigma conversion table to determine the sigma level, the steps required as follows:

a) Calculation of DPO

Knowing DPO (Defect Per Opportunities), which is a measure of failure, shows the number of defects in unity opportunities.

b) Calculation of DPMO

Calculating DPMO (Defect Per Million Opportunities) is a failure measure that shows the number of defects per million opportunities.

c) SQL Value (Sigma Quality Level)

Looking for the value of SQL (Sigma Quality Level) is an indicator that describes the level of process performance d) Yield Calculation

Yield is the probability that the product is not defective in the inspected process.

\section{- Analyze}

In the Analyze stage, the first thing to do is look for the type of dominant defect in Disc Brake products using the Pareto diagram; after finding the dominant defect that affects it, an analysis of the causes of the defect is carried out using a fishbone diagram. To determine the cause of the dominant defect, an interview was conducted with the production operator, the Quality Control supervisor.

\section{- Improve}

This improvement stage is when the problems found and explained are repaired in the Analyze stage using FMEA (Failure Mode Effect and Analysis). FMEA analysis was performed with an FMEA spreadsheet. Each problem of the 
problem is searched for the RPN value then the RPN value is arranged from the largest to the smallest value. The RPN value is the product of the severity, occurrence, and detection of each cause of the problem.

\section{- Control}

The control stage or the control stage is the last in the DMAIC method. The main goal at the control stage is to control the existing process so that problems that arise in the old process do not happen again. The control stage is carried out only in the form of a proposal to be implemented by the company.

\section{RESULT AND DISCUSSION}

\section{Analysis of Waste with Lean Manufacturing DMAIC and FMEA}

The problem that is the focus of discussion in this study is the occurrence of defects in the disc brake that is too high in the production line due to waste that does not add value to the product.

\section{(1) Define (Problem Identification)}

The problem discussed in this study is a defect in the form of thin material in Disk Brake products. Thin material is one of the defects in the disc brake caused by periodic replacement of components. Two tools are used at the define stage or problem identification, namely SIPOC (Supplier, Input, Process, Output, Customer) and CTQ (Critical to Quality). A SIPOC diagram is a process that shows activities in a business process after knowing the process on the disk brake product. Then analyzed using CTQ. The following are the results of the analysis from SIPOC and CTQ:

\section{- SIPOC diagram}

This analysis is very useful to find out who the supplier is for the input to the process, the specifications used on the input, who the customer is, and what the customer needs. Here are the results of the SIPOC diagram:

I. Supplier: This automotive company has collaborated with several vendors to provide the materials used during the production process.

II. Input: The material used in the manufacture of disk brakes is made of stainless steel. The composition of the material is Carbon (C), Manganese (Mn), Silicon (Si), Cromium (Cr), Sulfur (S), Phosphorus (P), and Nickel (Ni) and Silver Dye.

III. Process:

(a) Press: The raw material enters the press process to form diameter holes on the side of the disc brake.

(b) Heat Treatment: After being perforated, the iron is put into the heat treatment machine. This process is to get good strength and wear resistance.

(c) Cutting: Products that have gone through the Heat Treatment process, then enter the cutting process.

(d) Painting: This coloring process is a silver color.

(e) Grinding: This process is carried out to smooth the surface to a standardized extent.

(f) Riveting: Riveting is a method of joining metal pins that have a rivet head and handle.

(g) A.D. Inspection: This process is carried out to check the whole material using a machine.

(h) Last Inspection: The company carries out quality control by applying checking and marking.

(i) Final Inspection: At this stage it is carried out to reexamine the material by sampling.

(j) Packing: The process of packaging goods.
IV. Output

The results of the production carried out produce disk brake products.

\section{Customer}

The customers of Disk Brake products are Honda and Yamaha companies.

\section{- CTQ (Critical to Quality)}

CTQ analysis is needed to determine the characteristics of a product that is in accordance with consumer needs. Here are the results from the CTQ.

I. Burnt, the surface appearance of the product looks charred.

II. Rough, rough or uneven surface of the product.

III. Scratches, there are thin or thick scratches on the surface of the product.

IV. Thin material, the thickness of the disc brake product is very thin.

V. Slip, there is a deep scratch on the surface of the disc brake.

\section{(2) Measure}

At this stage, the measurement of the sigma value is carried out through the calculation of DPMO (Defect per Million Opportunity) and what is the probability that a product does not experience defects (Yield). Measurement at this stage is carried out to determine the company's performance as a basis for analysis and making improvements. The following is a calculation to determine the sigma value and probability of the Disk Brake product. Before analyzing the data, first the data adequacy and data uniformity tests were carried out.

\section{- Data Adequacy Test}

In the data sufficiency test, if $\mathrm{N} '<\mathrm{N}$ then the data is considered sufficient, but if $\mathrm{N}^{\prime}>\mathrm{N}$ data is considered insufficient and it is necessary to add data. So, the results of the data sufficiency test show that the data is sufficient because the value of $\mathrm{N} '<\mathrm{N}=3.53<12$ with a confidence level of $90 \%$ and an accuracy level of $10 \%$. After the data is sufficient, the next step is to test the uniformity of the data.

\section{- Data Uniformity Test}

The data is said to be uniform if it is between the two control boundaries, and non-uniform if it is outside the two control boundaries. Based on the uniformity test graphic image, it is known that the BKA value is 363.7 and the BKB value is 244.4 . Therefore, it can be stated that no data is outside the control limits. So, it can be said that the data used is uniform.

\section{- Determining the Sigma Level}

To find out the sigma level of Disk Brake products, it is necessary to do calculations. Based on the results of the calculation, it can be seen that the average sigma level of Disk Brake products based on production data and defects for the January 2019 - December 2019 period is 4.20, where DPMO or the number of defects is 3446.41 per one million opportunities with a probability of without defects of $98.29 \%$. In order to improve the quality of the company's sigma level, it is necessary to suggest appropriate improvements in order to reduce the number of defects that occur.

\section{(3) Analyze}

The next step after measuring (Measure) is Analyze. At this stage, an analysis of the problems that occur in the Disk Brake product is carried out after the previous calculations are carried out at the measure stage. It is hoped that at this stage the most significant defects in Disk Brake products will be known and the factors that cause defects in Disk Brake products. 
At this stage the tools used are the Pareto diagram and the fishbone diagram.

\section{- Pareto diagram}

In the pareto diagram it is known that the highest defect type is Thin Material with a percentage of $34.3 \%$, Slip $27.50 \%$, Burnt $22 \%$, Coarse $10.10 \%$ and Scratches $6.10 \%$. Therefore, the type of defect in thin material will be the focus for repairs. After it is known that the dominant defect type in Disk Brake product is thin material, then fishbone diagram tools are used to determine the cause of the defect.

\section{- Fishbone Diagram}

Based on the results of the Pareto diagram that has been done previously. that the biggest type of defect in disk brake products is thin material. Therefore, to determine the cause of the thin material defect on the disc brake, an analysis was carried out using a fishbone diagram obtained from the brainstorming results between researchers, supervisors and the head of quality control on May 19, 2020 at an automotive company.

Some of the factors that cause defects in thin material are as follows:

I. Human Factors

Humans are directly involved in the production process and have a very important role in the products produced.

(a) Not concentrating

Operators are less concentrated when working due to fatigue.

(b) Incorrect data entered

The operator entered the wrong data and forgot to change the data.

II. Material factors

Material is the raw material used to produce a product. If the materials used are good, it will produce a quality product.

(a) The quality of the material is not standard

The materials used in production come from a variety of suppliers. This is done so that you don't depend on just one supplier.

\section{Engine Factor}

Machines are tools used in the production process. If the machine used has a good performance, the resulting product will have good quality. (a) Machine life

An old machine results in instability in the performance of the engine. The maintenance system is very important because if the maintenance of the machine is well planned, it will not fail during production.

(b) Availability of components Availability of components in case of replacement is very important. Because when a component has passed its lifetime it will reduce its reliability value and can result in defective products.

\section{Method Factors}

A method is a method used in an activity process. If the method used is good, it will produce an optimal product.

(a) Poor procedure

The procedures used were not good, causing ineffective material control.

\section{Environment factor}

Environment is something that greatly affects the performance of an operator. Environmental causes:

(a) Noisy Environment

The noisy environment is caused by the noise from the machines when the production process is in progress.

\section{- FMEA}

Based on the FMEA table, it can be seen that the largest RPN is obtained from the availability of components due to irregular replacement of components resulting in a defective product in the form of thin material obtained with a value of 448 , then the age of the machine with a value of 336, the data entered does not match the value of 210 , no concentration with a value of 140 , non-standard material quality with a value of 60 , poor procedure with a value of 50 and the last one with a noisy environment with a value of 12 . The higher the RPN value, the greater the treatment that must be given to that cause.

\section{- $5 \mathrm{~W}+\mathbf{1 H}$}

After knowing the main causes of thin material defects in Disk Brake products through the results of the highest RPN in FMEA, then an action plan is carried out to solve the problem of thin material defects using $5 \mathrm{~W}+1 \mathrm{H}$ tools (What, Why, Where, When, Who, How). Following are the results of the $5 \mathrm{~W}+1 \mathrm{H}$ analysis:

TABLE 2: $5 \mathrm{~W}+1 \mathrm{H}$ analysis

\begin{tabular}{|c|c|c|}
\hline \multirow{2}{*}{$\mathbf{5 W}+\mathbf{1 H}$} & Types of Defects & Causative factor \\
\cline { 2 - 3 } & Thin Material & Availability of Components \\
\hline What & What is the improvement plan? & $\begin{array}{c}\text { Create a maintenance and component } \\
\text { replacement schedule }\end{array}$ \\
\hline Why & Why was it repaired? & $\begin{array}{c}\text { To reduce the number of defects } \\
\text { Where }\end{array}$ \\
\hline When & Where was the repair done? & $\begin{array}{c}\text { In the production area on disk brake product } \\
\text { machines }\end{array}$ \\
\hline Who & Who did the repair? & When it is approved by the quality manager \\
\hline How & How to make improvements? & $\begin{array}{c}\text { By running a maintenance schedule and } \\
\text { component replacement periodically }\end{array}$ \\
\hline
\end{tabular}


Based on Table 2 above, it can be seen that the proposed repair for Disk Brake product defects for the problem of component availability is to schedule maintenance and periodic component replacement.

\section{(4) Control}

This stage is the last in the DMAIC method. This stage contains suggestions or recommendations for the company to be consistent with the quality of the company. So that there will be no more the same problems later on. The following suggestions are given:

\section{- Material Control}

Checking each process regularly. Inspection by quality control is necessary, starting from the raw materials used then to semi-finished goods and the final process of finished products. All stages must be checked by quality control not to cause significant problems at the end of production.

\section{- Control of Machine}

Schedule component replacement and machine maintenance. Maintenance must follow the component replacement schedule, and all operators must be diligent in maintaining the machines used so that the production process can always run well and optimally.

\section{- Control over Man}

Operators must follow all SOPs that have been established in the company and carry out them in an orderly and correct manner. So that all production processes are expected to run smoothly.

I. Control over Method

The team responsible for making good and standardized SOPs was made. It is hoped that production operators can understand the SOP.

\section{Control of Environment}

Operators need to pay attention to the use of personal protective equipment (PPE) such as earplugs to reduce noise.

At the control stage there is a shift towards process control and to ensure that new suggestions for improvement can be made. The success or failure of this transition depends on the control. Control relates to who will be responsible for controlling and supervising and monitoring the next process. If the proposed maintenance and component replacement schedule has been implemented, an evaluation and repair will be carried out for any inconsistencies. However, in this control stage, it cannot be fully implemented. The author only provides suggestions for corrective actions to solve problems that occur in Disk Brake products.

\section{CONCLUSION}

Based on the results of calculations and analysis with the Disk Brake product quality control tool carried out in this study, the following conclusions were obtained:

(1) Based on the results of calculations that have been done with the Pareto diagram, it is known that the most significant type of defect in Disk Brake products is thin material defects with a percentage of $34.30 \%$ and the number of defects as many as 1253 parts.

(2) Based on the results of the analysis carried out using fishbone diagram tools, it is known that the causes of thin material defects include: 1) Incorrect data entered, 2) No concentration, 3) Non-standard material quality, 4) Availability of components, 5) Machine age, 6) Poor procedure.
(3) After analyzing using the DMAIC and FMEA methods, the recommended improvement to the company to overcome thin material defects is to periodically schedule the component replacement and machine maintenance.

\section{SUGGESTION}

The following suggestions are given from this research, either for companies or for further research, as follows:

(1) Company side

This research is expected of the company so that it can be applied to reduce defects in disc brake products.

(2) Other Party Research

It is hoped that further research with the same theme will complete it with an even better form.

\section{REFERENCES}

[1] Adrianto, W., \& Kholil, M. (2016). Analisis Penerapan Lean Production Process untuk Mengurangi Lead Time Process Perawatan Engine (Studi Kasus PT.GMF AEROASIA). Jurnal Optimasi Sistem Industri, 14(2), 299.

https://doi.org/10.25077/josi.v14.n2.p299309.2015

[2] Dambhare, S., Aphale, S., Kakade, K., Thote, T., \& Jawalkar, U. (2013). Reduction in rework of an engine step bore depth variation using DMAIC and Six Sigma approach: A case study of engine manufacturing industry. International Journal of Advanced Scientific and Technical Research, 3(2), 252-263.

[3] Gaspersz, v. (2010). Total Quality Management (TQM). PT Gramedia Pustaka Utama.

[4] Gaspersz, v. (2013). All-In-One Integrated Total Quality Talent Management. PR Percetakan DKU.

[5] Gaspersz, v, \& Fontana. (2007). Lean Six Sigma for Manufacturing and Services Industries. PT Gramedia Pustaka Utama.

[6] Guo, W., Jiang, P., Xu, L., \& Peng, G. (2020). Integration of value stream mapping with DMAIC for concurrent Lean-Kaizen: A case study on an air-conditioner assembly line. Advances in Mechanical Engineering, 11(2), 1-17.

https://doi.org/10.1177/1687814019827115

[7] Haryanto, E.., \& Bonivasius, P. (2020). ANALISA PENURUNAN CACAT (DEFECT) CAT BINTIK DEBU DENGAN METODOLOGI SIX SIGMA PADA PROSES PAINTING PRODUK FUEL TANK DI PT. SSO TANGERANG 1 Endi Haryanto dan 2 Bonivasius Prasetya Ichtiarto. XIII (3), 326-337.

[8] Hidayat, A. A., Kholil, M., Hendri, \& Suhaeri. (2018). The Implementation of FTA (Fault Tree Analysis) and FMEA (Failure Mode and Effect Analysis) Methods to Improve the Quality of Jumbo Roll Products. IOP Conference Series: Materials Science and Engineering, 453(1). https://doi.org/10.1088/1757899X/453/1/012020

[9] Kholil, M, \& Syukron. (2013). SIX SIGMA: Quality for Business Improvement. Graha Ilmu.

[10] Kholil, M, Syukron, \& Amin. (2013). Six Sigma for Business Improvement. Graha Ilmu. 
[11] Kholil, Mohammad, \& Prasetyo, E. D. (2017). Tinjauan Kualitas Pada Aerosol Can Ø 65 X 124 Dengan Pendekatan Metode Six Sigma Pada Line Abm 3 Departemen Assembly. Sinergi, 21(1), 53. https://doi.org/10.22441/sinergi.2017.1.008

[12] Kholil, Muhammad, \& Pambudi, T. (2010) Implementasi Lean Six Sigma Dalam Peningkatan Kualitas Dengan Mengurangi Produk Cacat Ng Drop Di Mesin Final Test Produk Hl 4.8 Di Pt. Ssi. Jurnal PASTI.

[13] Matathil, A., N, G. K., \& Ramachandran, K. (2012). Reduction of Scrap in an Electronic Assembly Line Using DMAIC Approach. SASTECH Journal, 11(2), 5359.

[14] McDermott, \& Robbin, E. (2009). The Basics of FMEA 2nd Edition. Taylor \& Francis Group.

[15] Haekal, J., Hanum, B., \& Adi Prasetio, D. E. 2020. Analysis of Operator Body Posture Packaging Using Rapid Entire Body Assessment (REBA) Method: A Case Study of Pharmaceutical Company in Bogor, Indonesia. International Journal of Engineering Research and Advanced Technology - IJERAT (ISSN: 2454-6135), 6(7), 27-36.

[16] Hanum, B., Haekal, J., \& Adi Prasetio, D. E. 2020. The Analysis of Implementation of Enterprise Resource Planning in the Warehouse Division of Trading and Service Companies, Indonesia. International Journal of Engineering Research and Advanced Technology IJERAT (ISSN: 2454-6135), 6(7), 37-50.

[17] Kholil, M., Haekal, J., Eko Adi Prasetio, D., \& Sulaiman Hasan. 2020. The Lean Manufacturing Design for Improving Production Scheduling Using Product Wheel Method in Chemical Manufacturing Company, Indonesia. International Journal of Engineering Research and Advanced Technology - IJERAT (ISSN: 2454-6135), 6(8), 12-18.

[18] Haekal, J., \& Setio, H. 2017. Selection of Raw Material Suppliers Using Analytical Hierarchy Process in Food and Beverage Company, South Jakarta. ComTech: Computer, Mathematics and Engineering Applications, 8(2), 63-68.

[19] HAEKAL, J. (2018). PERANCANGAN DAN EVALUASI IMPLEMENTASI SISTEM MANAJEMEN MUTU ISO 9001: 2015 MELALUI KEPUASAN PELANGGAN DI UNIVERSITAS ISLAM AS-SYAFI'IYAH (Doctoral dissertation, Universitas Mercu Buana Jakarta).
[20] Kholil, M., Haekal, J. H, Sulaiman. 2020. Lean Manufacturing Design to Reduce Waste in Gear Production Process Using VSM and Kaizen Method Approaches (Case Study: Gear Primary Driven K56 Product). Journal of Scientific and Engineering Research. 7(8), 1-9

[21] Haekal, J., \& Prasetio, D. E. A. Planning of Production Facilities Layouts in Home Industry With The Systematic Layout Planning Method.

[22] haekal, J., \& Setiawan, I. (2020). Comparative Analysis of Raw Materials Control Using JIT and EOQ method For Cost Efficiency of Raw Material Supply in Automotive Components Company Bekasi, Indonesia. International Journal of Engineering Research and Advanced Technology (ijerat), 6(10), 76-82. https://doi.org/10.31695/IJERAT.2020.3661

[23] Haekal, J., Hanum, B., \& Adi Prasetio, D. E. 2020. Application of Quantitative Strategic Planning Matrix (QSPM) For Determination of Alternative Strategies in Food and Beverage SMES in Bogor Indonesia. Journal of Scientific and Engineering Research. 7(7), 137-145

[24] Hanum, B., Haekal, J., \& Adi Prasetio, D. E. 2020. SPHC Material Inventory Control Analysis in Project VL01 Centralized by the EOQ Method in Automotive Company Indonesia. Journal of Scientific and Engineering Research. 7(7), 130-136

[25] Muhsin, A., Djawoto, Susilo, P., \& Muafi. (2018). Hospital performance improvement through the hospital information system design. International Journal of Civil Engineering and Technology, 9(1), 918-928.

[26] Prasetyo, E. D. (2015). Analisa produksi pada AEROSOL CAN Ø 65 X 124 DENGAN MENGGUNAKAN METODE PENDEKATAN SIX SIGMA PADA. VIII (2), 191-202.

[27] Syaifulloh. (2014). Analisa Pengendalian Kualitas Aerosol Can dengan Menggunakan Metode DMAIC pada Line ABM 1 di Perusahaan Perkalengan Indonesia. Jurnal PASTI, viii, 340-348.

[28] Tannady. (2015). Pengendalian Kualitas. Graha Ilmu.

[29] Uddin, S. M., \& Rahman, C. M. L. (2014). Minimization of Defects in the Sewing Section of a Garment Factory through DMAIC Methodology of Six Sigma. Research Journal of Engineering Sciences, 3(9), 21-26.

[30] Wahyuni, H. C. (2015). Pengendalian Kualitas. Graha Ilmu. 